\title{
A Scenario of the Impact of a Future Climate Change on World Food Production
}

\author{
Robert Schware and William W. Kellogg \\ National Center for Atmospheric Research* \\ Boulder, Colorado 80307
}

Most climatologists agree that if we continue to burn fossil fuels we will further increase the atmospheric concentration of carbon dioxide, and the resulting "greenhouse effect" will generally warm the surface of the Earth in the decades ahead (1). Our purpose here is to present one scenario of a global climatic change and its impact on regional food production; the implications could be potentially serious. Because the impacts of a long term climate change could be adverse for some (and good for others), policy makers need to assess how each of the following could be affected: the productivity of each agricultural area; the availability of food supplies; and the continued viability of long term food import and export agreements.

In order to study some implications of a future carbon dioxide-induced climatic change we should start with as detailed a description as possible of plausible long term changes of patterns of temperature and rainfall. Since climatologists are not yet prepared to make such detailed predictions, one way to do this is by illustrating a range of conditions *The National Center for Atmospheric Research is sponsored by the National
Science Foundation. 


\section{DISCLAIMER}

This report was prepared as an account of work sponsored by an agency of the United States Government. Neither the United States Government nor any agency Thereof, nor any of their employees, makes any warranty, express or implied, or assumes any legal liability or responsibility for the accuracy, completeness, or usefulness of any information, apparatus, product, or process disclosed, or represents that its use would not infringe privately owned rights. Reference herein to any specific commercial product, process, or service by trade name, trademark, manufacturer, or otherwise does not necessarily constitute or imply its endorsement, recommendation, or favoring by the United States Government or any agency thereof. The views and opinions of authors expressed herein do not necessarily state or reflect those of the United States Government or any agency thereof. 


\section{DISCLAIMER}

Portions of this document may be illegible in electronic image products. Images are produced from the best available original document. 
that might occur through climate scenarlos. Figure 1 is an example of just one such scenario; it shows the regions that may be wetter or drier than now in a future warmer climate. This information was then combined with data on world food productivity to show some kinds of crops that could be affected by climate-1nduced changes in soll moisture.

Clearly a great deal more information about the causes of climate change combined with energy consumption scenarios will be needed before we can be confident that this kind of scenario is a credible forecast. While It may not give policy makers and planners any guarantees about the future, the scenario can indicate the possible impact on food production of the change to a warmer climate.

The following assumptions were made when preparing the map of possible changes in soil molsture shown in Figure 1: that, at.least for the next several decades, 1ncreasing quantities of carbon dioxide would be released Into the atmosphere by worldwide burning of fossil fuels (coal, petroleum, natural gas); that this carbon dioxide would warm the Earth by the well recognized "greenhouse effect;" and that early in the next Century the average surface temperature would increase by 2 to $3^{\circ} \mathrm{C}$; that such a global warming would alter the large scale atmospheric circulation patterns that determine the weather and climate of each region; and that we can grasp some of the main features of these changes by studying past climate changes and by conducting experiments with current climate models (2).

The last assumption deserves some further explanation here, since $1 t$ 1s probably the most controversial. There was a climatic perlod known as 
the Altithermal (or Hypsithermal) some 4500 to 8000 years ago when the Earth was generally warmer by several degrees, especlally at middle and high latitudes. At that time the patterns of rafnfall and vegetation were very differen't from the present, and paleoclimatologists have pleced together those patterns (3). Other recent studies have 1dentifled the anomalous precipitation patterns that prevailed in this century when the Northern Hemisphere was warmer than average at high latitudes, in the Arctic and sub-Arctic (4). A third source of evidence on precipitation and soll molsture distribution on a warmer Earth is the experiments with climate models, in which a model with present boundary conditions is compared to a model with doubled carbon dioxide--a condition that could prevail before the middle of the next Century (1)(2). In this case the soll moisture is calculated from the difference between average precipitation and evaporation (5).

All of these sources of information were consulted, and regions of agreement and disagreement regarding prectpitation, soll moisture, and vegetation conditions were noted. The areas where there was a consensus as to the trend are outlined by dashed Iines in Figure 1 and labeled "wetter" or "drier." It is reasonable to assume that at least in these areas of general agreement the probability of a specified change occuring is higher than in regions where the evidence is conflicting. Nevertheless, we must emphasize that this climate scenario should not be considered a prediction of things to come, but rather an 1llustration of the regional patterns of 
change of soll molsture that could occur. Furthermore, it is virtually impossible at this stage to be quantitative about these regional changes. Bearing these potential changes in mind, we next looked at the patterns of current world food production and considered how they might be altered. World food production data are given for the nine major crops in 1978, as shown in Figure 2, drawn from reports published by the Food and Agricultural Organization (6). The five largest crops--wheat, rice, maize, potato, and barley-are further broken down by major producers and percentage of total for each crop (Ffgure 3 ). The percentage of each crop that may be affected by wetter or drier soll molsture conditions is shown in the top portions of every figure.

Future drier and warmer conditions could occur in areas where roughly 50 percent of the world's wheat and 55 percent of the world's maize produced was grown in 1978. On the other hand, approximately 86 percent of the world's rlce, 60 percent of the world's potatoes, and 50 percent of the world's barley could be affected by wetter soil conditions. Unfortunately it is not possible to calculate the actual changes in crop production that mighe occur as a result. Ordinarily, drler and hotter conditions in the grain producing countries will be detrimental, but not invariably. Furthermore, recalling that the climatic change will be brought about by Increasing carbon dioxide, we should expect this factor to encourage photosynthesis and improve the efficlency of water utilization of crops (7). 
In a world with a steadily growing population the avallability of enough food poses a major problem, and the potential for growing more good is receiving much attention. The global climatic change will be a factor to be considered-though by no means the only one: the distribution of food is currently the main cause of famine, not the total world production.

It is especially important to consider which countries will be Involved-those whose food production could be modified by a change in present soil moisture and temperature conditions. For example, the U.S. accounted for nearly half of the world production of malze in 1978. According to the scenarlo, a large portion of 1 ts current production areas may become drfer and hotter in the future. The U.S.S.R. produced almost one-third of the world's wheat, potatoes, and barley in 1978.: Under the range of conditions that could plausibly occur, practically all of these Soviet crops could face drier soil conditions. China and India accounted for over half of the world production of rice in 1978. Their soil moisture could be wetter than now.

- These shifts in climatic patterns and consequent effects on agricultural productivity, should they occur, will almost surely change the balance of world food trade. For Instance, the U.S. dominates the proportion of world exports: In 1978, it accounted for about 41 percent of the world wheat exports, 73 percent of maize, and 23 percent of rice (6). A shift of climate in the U.S. as suggested by our climate scenario could make these sizeable exports difficult, if not 1mpossible, to sustain. 
Under generally warmer and wetter conditions, rice ylelds may Increase in the major producing countries of China, India, Indonesia, Bangladesh, Thalland, and Japan--primarily as a result of longer growing seasons. This could be beneficial to their economic, trade. In 1978 China accounted for over 16 percent and Thailand 16 percent of the world's total export in rice.

Obviously, countries vary in the degree to which they have become dependent on international food markets. Those with relatively minor involvement in the international food trade may be less affected by climate-induced changes in the balance of trade than countrles heavily involved. For example, both China and the U.S.S.R. Import a relatively significant fraction of their domestic wheat consumption; the same applies to Braz11, China, and the U.S.S.R. with respect to maize. Eastern European countries in turn rely heavily on the U.S.S.R. for their grain supplies. Major shifts in the production of any of these countries may require adjustments in the patterns of international food trade and renegotiation of existing Import and export commodity agreements (8).

The Impact of changing. climate sonditions on domestic grain availability and consumption is significant as well. A sizable percentage of most countries' grain production is used internally, efther to bufld up stored reserves or for 1mmediate consumption. Table 1 illustrates the heavy dependence for some countries on food "avaflability" (shown here as a percentage of crop production, taking account of imports and exports). Large wheat exporting countries, for example, such as Canada, France, and 
the U.S., may have to reduce exports and resort more to feeding themselves. If they are faced with the need to divert graln exports for domestic use in the face of decreased production at home, these large current exporters will obvlously have a better chance to feed their own population but at the expense of a valuable export commodity.

Hence it is against this background of climatological uncertainty, and the prospect of possible shifts in patterns of food production, that the development of strategles to cope with or avert the climate change must be seen. If strategles are developed and implemented that can decrease our vulnerability to the inevitable year-to-year fluctuations of climate and crop production--strategies that make sense now--then we will be better equipped to cope with a more gradual climate change if. It occurs in the decades ahead (9).

Robert Schware William W. Kellogg Advanced Studies Program National Center for Atmospheric Research Boulder, Colorado 80307. 


\section{References and Notés.}

1. Carbon Dioxide and Climate: A Sclent1f1c Assessment (Cl1mate Research Board, National Academy of Sclences, Washington, D.C., 1979); Proc. of the World Climate Conf. (World Meteorological Organizat1on, Rept. No. 537, Geneva, 1979); Report of the Meeting of CAS Work1ng Group on Atmospher1c Carbon Dloxide. Proj. on Res. and Monitoring of $\mathrm{CO}_{2}$, Rept. No. 2 (World Meteorological Organization, Geneva, 1979).

2. All of these polnts are discussed in W.W. Kellogg and R. Schware, Climate Change and Soclety: Consequences of Increasing Atmospheric Carbon Dloxide (Westview Press, Boulder; 1981); W.W. Kellogg, Ann. Rev. Earth Planet Sc1. 7, 63-92.

3. For example, $\dot{K}$. Butzer, Prof. Geographer 32, 269-278; W.W. Kellogg, in Climaric Change, J. Gribbin, Ed. (Cambridge University Press, Cambr1dge, 1978), 205-227.

4. T.M.E. Wigley, P.D. Jones and P.M. Kelly, Nature 283, 17-20 (1979); J. ,Wililams, C11mat1c Change, 2, 249-266. (1979).

5. S. Manabe, and R.T. Wetherald, J. Atmos. Sc1. 37, 99 (1980); R.T. Wetherald and S. Manabe, J. Geophys. Res. (In press).

6. Food and Agriculture Organization, Production Yearbook No. 22, Vol. 32 (Food and Agriculture Organization, Rome, 1979).

7. S.H. Wittwer, J. So11 and Water Conservation 35, 3, 116-120 (1980).

8. International Economic Studies Inst1tute, Raw Materials and Fore1gn Pollcy (International Economic Studies Institute, Washington, D.C., 1976); R. Garc1a, Nature Pleads Not Gullty (Pergamon Press, New York, In press).

9. The authors are grateful. for useful comments on the manuscript by Derek W1nstanley, Stephen H. Schneider, and Donald Borock. 
Figure 1. Example of a scenario of possible soll moisture patteris on a warmer Earth. It is based on paleoclimatic reconstructions of the Altithermal Period (4500 to 8000 years ago), comparisons of recent warm and cold years in the Northern Hemisphere; and a climate model experiment. (For a discussion of these sources of Information see Ref. 2). Where two or more of these sources agree on the direction of the change we have indicated the area of agreement with a dashed line and a label. 


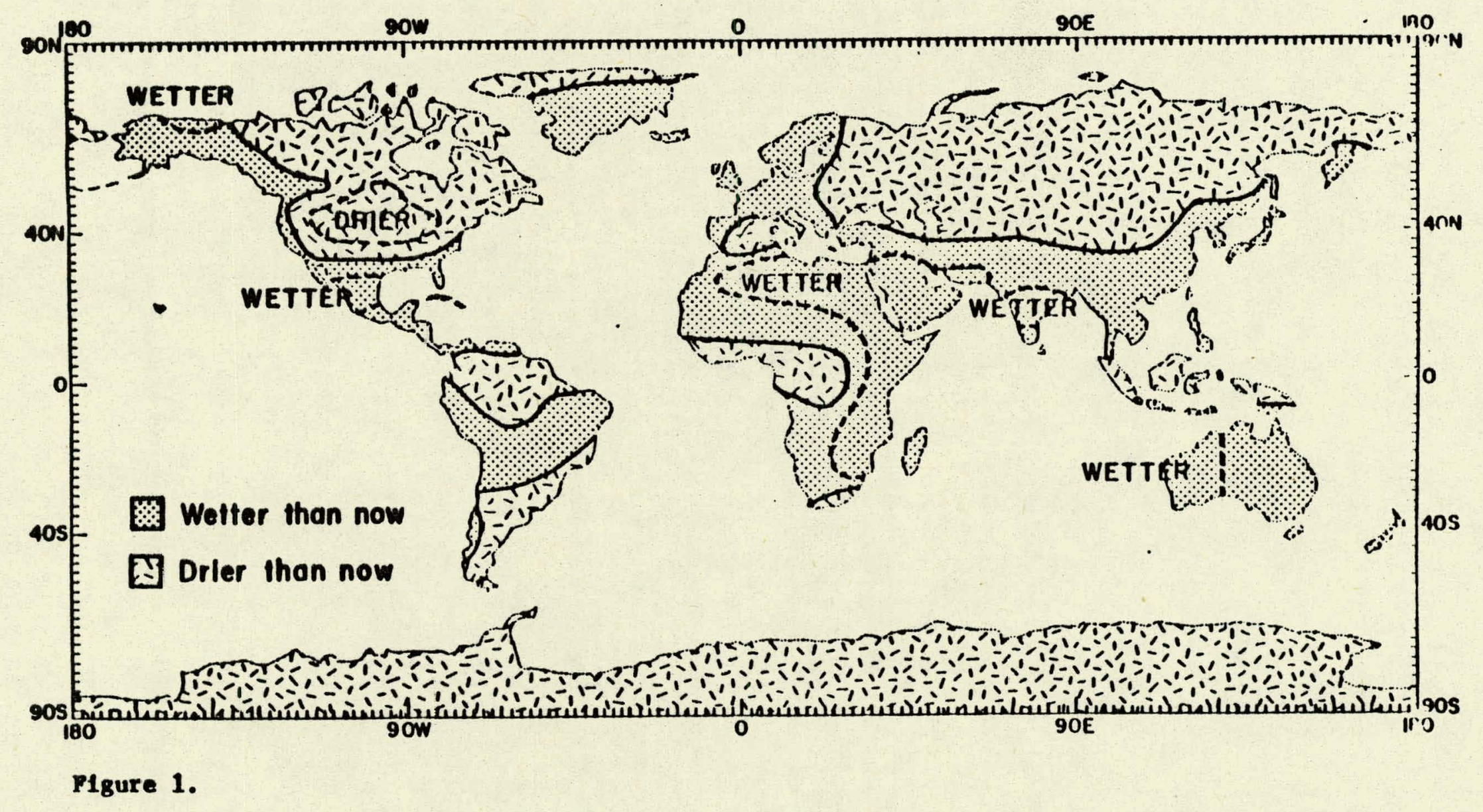


Figure 2. Annual production of the world's nine major food crops in 1978. Compiled from FAO data (1979). 


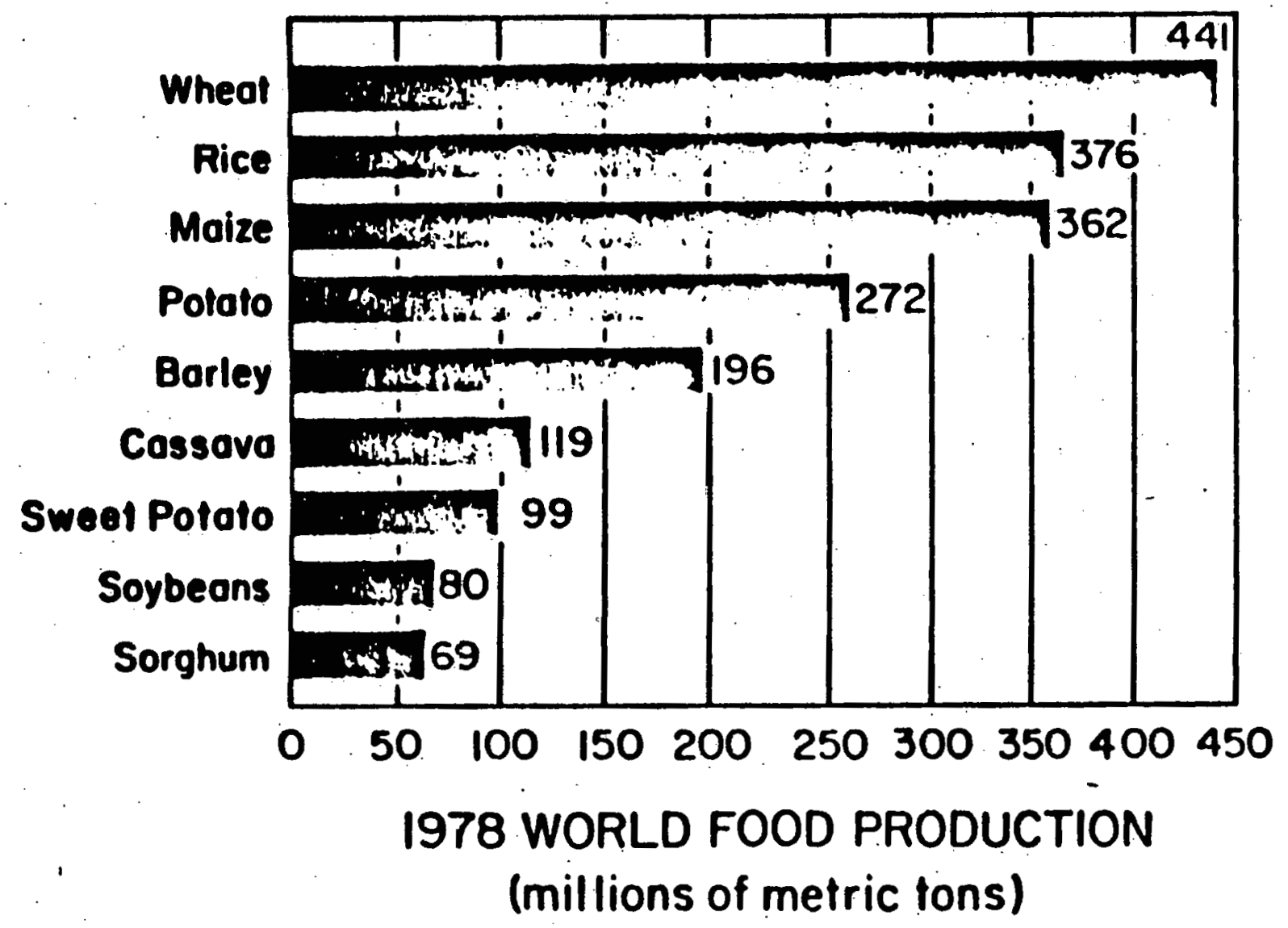

5

Pigure 2. 
Figure 3. World food production for some major crops in 1978 combined with a scenario of posstble soll molsture patterns on a warmer Earth. Areas marked "Drier than now" and "Wetter than now" are derived from Figure 1. World food production data compiled from FAO (1979). 


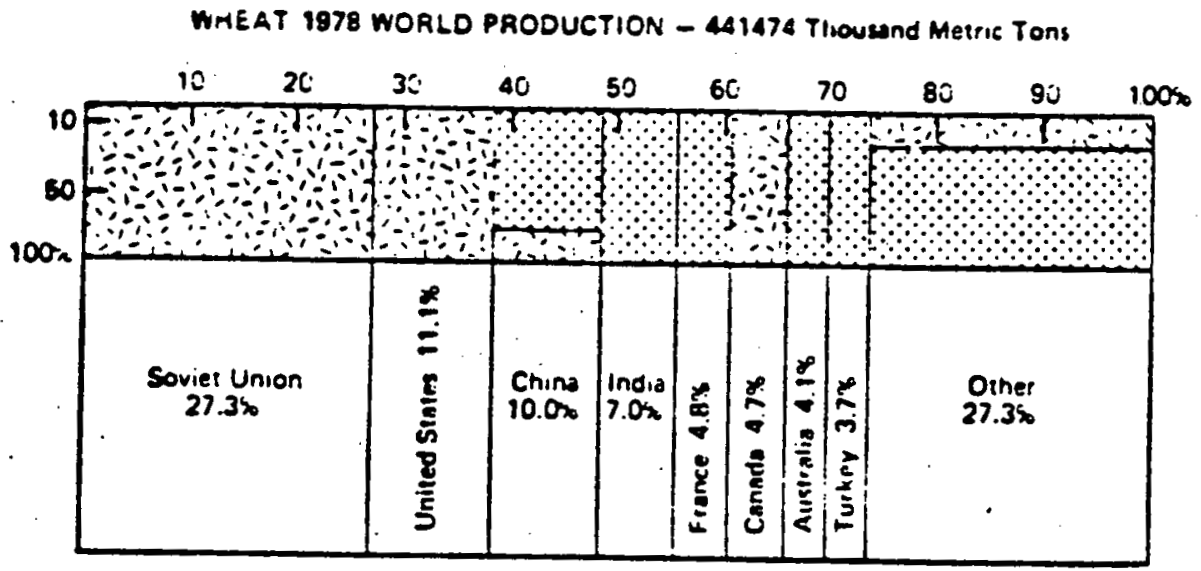

RICE 1978 WORLD PRODUCTION - 376448 Thousend Motric Tons

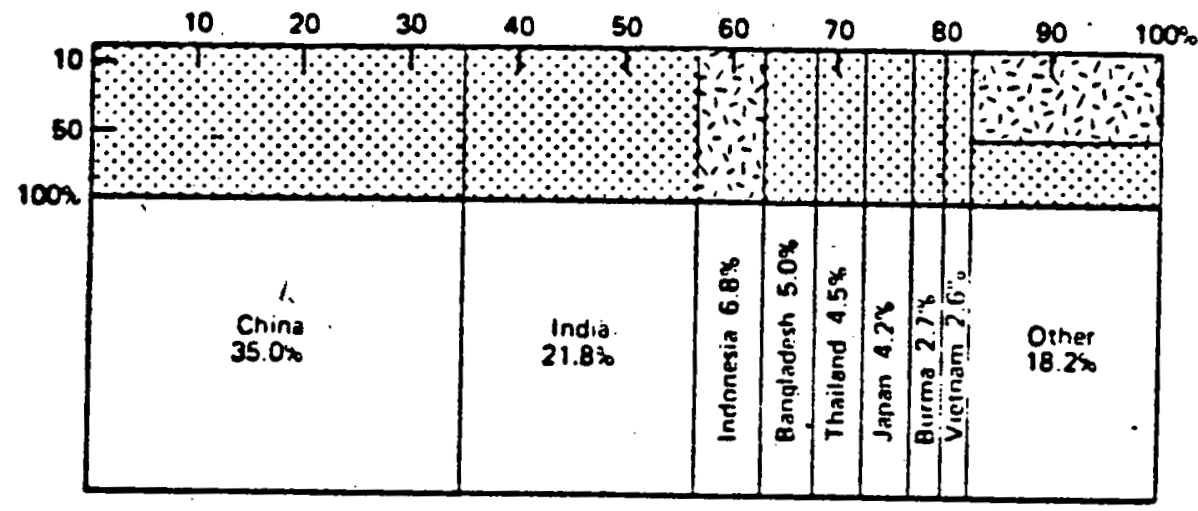

MAIZE (Com) 1978 WORLD PRODUCTION - 362971 Thousend Metric Tons
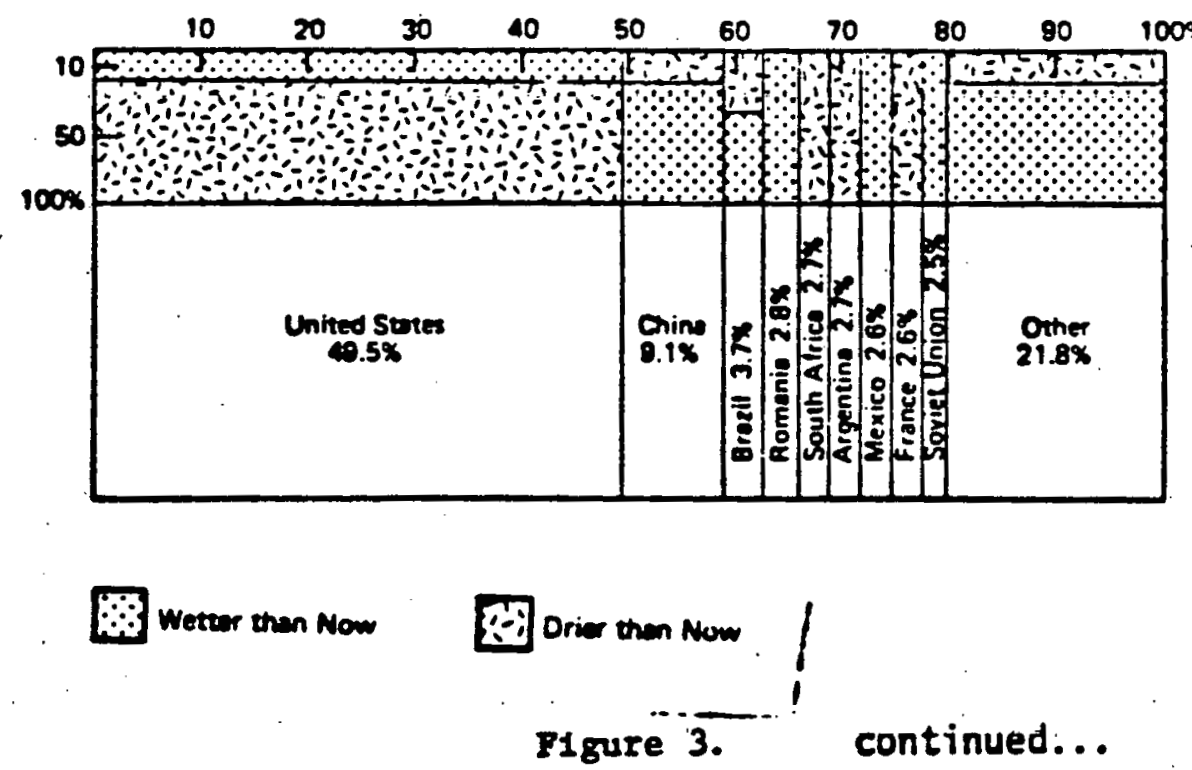

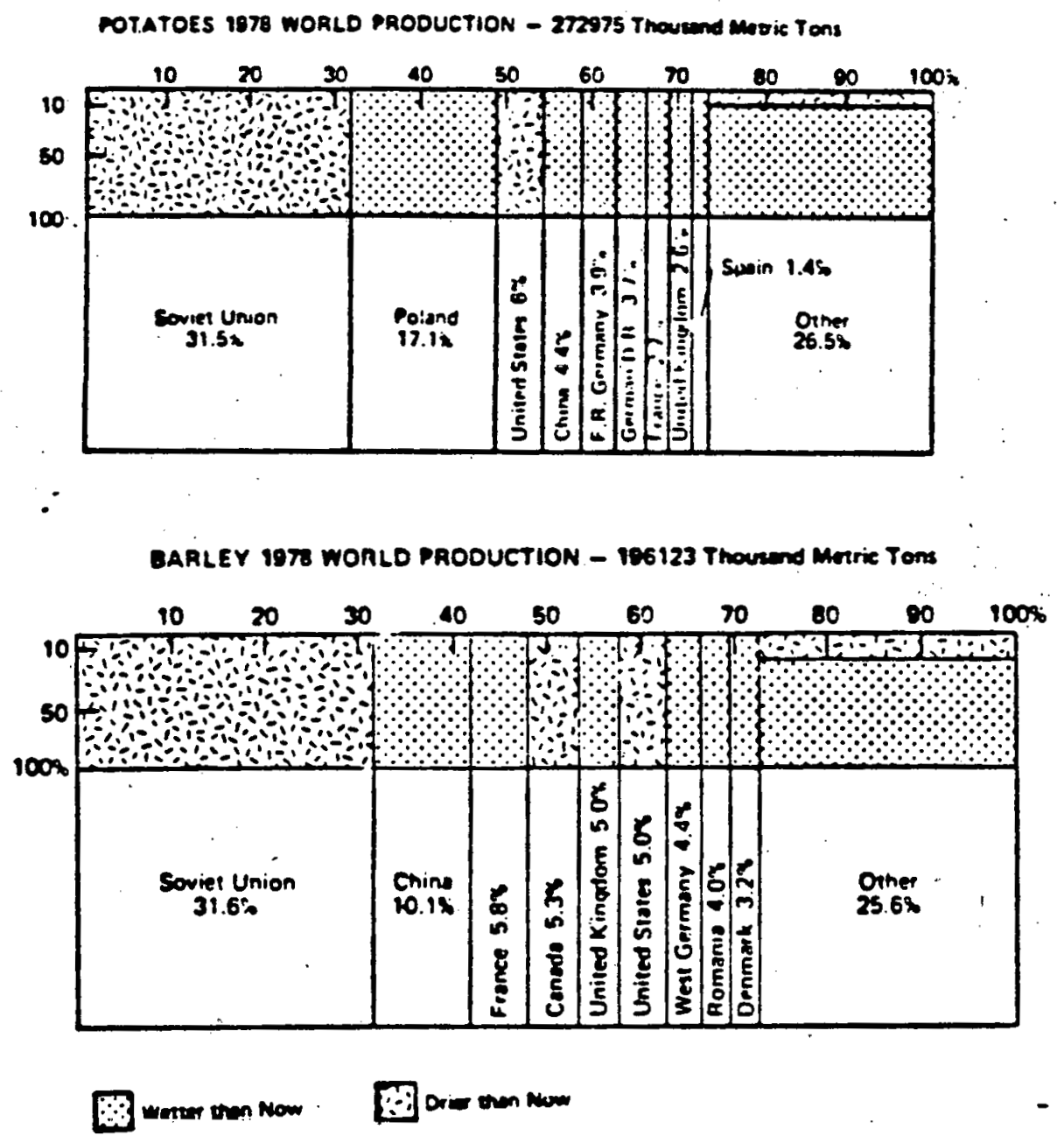

Figure 3. 
Table 1. Production and domestic avallability for major producing countrles and three major crops.

1978 Crop Productiona/Domestic Avallabilityb

Country

Bangladesh

Braz11

Burma

Canada .

China

France

India

Indonesia

Mexico

Romania

South Africa

Tha1land

Turkey

USA

U.S.S.R.

Vietnam
Wheat

Rice

$18900 / 102$

$13500 / 111$

$10500 / 97$

$21100 / 28$

$44003 / 119$

$21100 / 65$

$31300 / 98$

$7900 / 100$

$25700 / 107$

$$
132000 / 99 \text {. }
$$

$33100 / 101$

$9473 / 82$

$9620 / 114$

$10179 / 92$

$9930 / 72$

$17000 / 91$

$16500 / 87$

$49000 / 27$

$18000 / 97$

$9000 / 231$

$.9880 / 102$

In 1000 MT. Rounded to three significant figures.

bpercentage of production taking account of exports and 1nports. A country with more than 100 percent must be a relatively large importer of that commodity. Data. compiled from FAO (6). 